\title{
PENYUSUNAN MEDIA PEMBELAJARAN BERBANTUAN KOMPUTER UNTUK PBL DAN KEEFEKTIFANNYA TERHADAP CTS PESERTA DIDIK SMA
}

\author{
Atik Kurniawati ${ }^{1)}$, I Gusti Putu Suryadarma ${ }^{2)}$ \\ Prodi Pendidikan Sains PPs UNY ${ }^{1)}$, Universitas Negeri Yogyakarta ${ }^{2)}$ \\ cuby_gimanaya@yahoo.co.id ${ }^{1)}$, samodhaya@yahoo.com ${ }^{2)}$
}

\begin{abstract}
Abstrak
Penelitian ini bertujuan untuk menganalisis: (1) kelayakan media pembelajaran berbantuan komputer berbasis problem based learning (PBL) pada materi Pencemaran Lingkungan untuk peserta didik SMA kelas X, dan (2) kefektifan media pembelajaran untuk meningkatkan kemampuan berpikir kritis (critical thinking skill, CTS) peserta didik kelas X SMA Negeri 5 Kota Magelang. Penelitian ini termasuk penelitian pengembangan yang diadaptasi dari model ADDIE meliputi analyze, design, develop, implement, dan evaluate. Produk divalidasi oleh ahli materi, ahli media, pendidik Biologi, dan teman sejawat. Subjek coba pada penelitian ini adalah peserta didik kelas X SMA Negeri 5 Magelang. Pengumpulan data menggunakan angket, lembar observasi, dan tes kemampuan berpikir kritis. Kelayakan media pembelajaran berdasarkan penilaian validator dan peserta didik termasuk dalam kategori baik. Media pembelajaran terbukti efektif untuk meningkatkan kemampuan berpikir kritis peserta didik yang ditunjukkan oleh nilai signifikansi sebesar 0,00 . Sehubungan dengan itu media pembelajaran berbantuan komputer berbasis PBL layak digunakan dan efektif untuk meningkatkan kemampuan berpikir kritis peserta didik.
\end{abstract}

Kata kunci: Media pembelajaran berbantuan komputer, PBL, CTS

\section{EFECTIVENESS OF COMPUTER-ASSISTED LEARNING MEDIA BASED PBL FOR IMPROVING THE STUDENST CTS}

\begin{abstract}
This study aims to investigate: (1) the feasibility of computer-assisted learning media based problem based learning (PBL) on Environmental Pollution materials for high school students of class $X$, and (2) the effectiveness of instructional media for improving of critical thinking skill (CTS) learners class X SMA Negeri 5 Magelang. This research was adapted from the ADDIE model of development that includes analyze, design, develop, implement, and evaluate. Products validated by subject matter experts, media experts, educators of Biology, and peer reviewer. Subject of this study is tenth grade students of SMA Negeri 5 Magelang. Collecting data was using questionnaires, observation sheets, and test critical thinking skills. The media according to the validator and the students is classified to the category of good. Instructional media was improved to learners' critical thinking skills effectively, which demonstrated by the significant value of 0:00. This results showed that media computer-assisted learning based PBL is effective for improving of the critical thinking skills of learners.
\end{abstract}

Key words: Computer-assisted learning media, PBL, CTS 


\section{PENDAHULUAN}

Teknologi memiliki peran penting dalam kehidupan manusia, sehingga manusia memperoleh berbagai kemudahan dalam memenuhi kebutuhannya. Kesadaran akan peran teknologi memberi dampak pada perkembangan ilmu pengetahuan untuk mencari inovasi baru yang semakin memudahkan manusia. Perkembangan ini menuntut kesiapan setiap individu dalam menghadapi arus perubahan di dalamnya. Untuk itu dibutuhkan keputusan yang rasional dan bertanggung jawab dalam meng-atasi setiap persoalan. Kemampuan melakukan analisis, sintesis, dan evaluasi secara logis, kritis, kreatif, dan produktif merupakan keterampilan berpikir tingkat tinggi yang diperlukan dalam membuat keputusan yang rasional dan bertanggung jawab. Oleh karena itu, setiap individu perlu membekali diri dengan mengoptimalkan keterampilan berpikir tingkat tinggi (higher order thinking). Salah satu bagian dari keterampilan ini berupa kemampuan berpikir kritis (Johnson, 2009, p.182).

Berpikir kritis merupakan proses yang terarah dan jelas yang digunakan dalam kegiatan mental seperti memecahkan masalah, mengambil keputusan, membujuk, menganalisis asumsi, dan melakukan penelitian ilmiah (Johnson, 2009, p.182). Berpikir kritis merupakan pencapaian pemahaman yang mendalam. Seseorang dapat mengerti maksud di balik ide yang mengarahkan hidupnya setiap hari. Aspek kehidupan modern berdampak pada semakin kompleksnya permasalahan yang dihadapi. Oleh karena itu, perlu upaya menumbuhkan dan mengembangkan kemampuan berpikir kritis.

Pengembangan kemampuan berpikir kritis sejalan dengan tujuan pendidikan Biologi yang tertulis dalam standar isi. Tujuan tersebut mengisyaratkan pentingnya kemampuan berpikir kritis untuk dimiliki oleh peserta didik.

Berdasarkan hasil studi Trends in International Mathematics and Science Study (TIMSS) tahun 2011 menunjukkan bahwa kemampuan berpikir tingkat tinggi dan penguasaan konsep peserta didik di Indonesia belum optimal. Hasil TIMSS tahun 2011 menunjukkan rata-rata skor prestasi sains untuk peserta didik Indonesia sebesar 406 yang jauh di bawah skor rata-rata internasional sebesar 500. Kedudukan Indonesia berada pada peringkat 39 dari 41 negara peserta. Jika dibandingkan negara kawasan Asia Tenggara, rata-rata skor prestasi sains Indonesia tergolong rendah.
Berdasarkan wawancara dengan pendidik di SMA Negeri 5 Magelang yang mengampu mata pelajaran Biologi kelas $\mathrm{X}$ diperoleh informasi bahwa kemampuan peserta didik untuk tingkat analisis masih rendah. Hasil UN tahun 2010/2011 menunjukkan bahwa perolehan rerata skor Biologi SMA Negeri 5 Magelang menduduki peringkat terakhir di antara SMA negeri di Magelang.

Kemampuan peserta didik di Indonesia yang rendah cukup memprihatinkan, sehingga memerlukan tindakan untuk memperbaiki kondisi ini. Strategi untuk melakukan perbaikan di antaranya melalui perbaikan proses pembelajaran. Penerapan model pembelajaran berbasis masalah merupakan solusi tepat untuk mengoptimalkan kemampuan berpikir kritis peserta didik (Arnyana, 2005; Yuan et al., 2008; dan Ali $\&$ Rubani, 2009).

Sanjaya (2008, p.216) menyatakan bahwa masalah yang diangkat dalam PBL bersifat terbuka, sehingga jawaban dari masalah yang bersifat belum pasti. Peserta didik mempunyai kesempatan luas untuk bereksplorasi, mengumpulkan dan menganalisis data secara lengkap untuk memecahkan masalah yang dihadapi. Proses membahas dan mengkritisi suatu masalah dapat membuat peserta didik memiliki ingatan yang lebih membekas dan memperoleh pembelajaran yang bermakna. Salah satu masalah yang tidak luput dari perjalanan hidup peserta didik di masa kini dan masa mendatang adalah masalah lingkungan. Masalah pencemaran lingkungan selama beberapa tahun terakhir banyak bermunculan. Oleh karena itu, masalah pencemaran lingkungan merupakan materi yang sesuai untuk diangkat dalam proses pembelajaran. Selain itu, peningkatan kesadaran dan partisipasi peserta didik dalam menjaga kelestarian lingkungan merupakan salah satu tujuan mata pelajaran Biologi.

Pembelajaran lingkungan lebih tepat jika dilakukan di alam sekitar secara langsung, walaupun di lapangan banyak ditemui keterbatasan dalam melaksanakannya. Kondisi alam sekitar belum tentu sesuai dengan skenario pembelajaran, serta kendalan keterbatasan waktu yang tersedia. Masalah pencemaran lingkungan terkait dengan proses yang tidak bisa diamati dalam waktu singkat. Oleh karena itu, pendidik perlu alat bantu untuk mengatasi keterbatasan pelaksanaan pembelajaran.

Media pembelajaran berbantuan komputer dapat menampillkan gambaran kondisi lingkungan seperti realita yang disertai dengan suara 
dan gerakan atau gambar bergerak. Media pembelajaran ini dapat menampilkan teks yang berisi masalah lingkungan yang disertai video untuk memperjelas pemaparan masalah, sehingga peserta didik dapat mengobservasi masalah lingkungan secara tidak langsung. Selain itu, penggunaan media pembelajaran berbantuan komputer dapat digunakan bagi pembelajaran yang alokasi waktunya sedikit untuk melakukan observasi ke objek pembelajaran secara langsung.

Media pembelajaran berbantuan komputer untuk pembelajaran berbasis masalah sangat bermanfaat untuk membantu keefektifan proses pembelajaran untuk penyampaian pesan dan isi pelajaran. Selain membangkitkan motivasi dan minat peserta didik, media pembelajaran, juga dapat membantu peserta didik dalam meningkatkan pemahaman, menyajikan data dengan menarik dan memadatkan informasi (Winarno, 2009, p.2). Penggunaan komputer dalam pembelajaran juga dapat memberi dampak positif terhadap kemampuan berpikir tingkat tinggi peserta didik (Gokhale, 1996), khususnya kemampuan berpikir kritis (McMahon, 2009).

Pendidik di SMA N 5 Magelang belum menggunakan media pembelajaran berbantuan komputer yang interaktif untuk pembelajaran berbasis masalah. Kondisi ini terjadi dikarenakan berlum tersedianya media jenis ini. Sehubungan dengan itu, penelitian ini berupaya untuk menyusun media pembelajaran berbantuan komputer untuk pembelajaran berbasis masalah pada materi Pencemaran Lingkungan. Selain itu diharapkan media pembelajaran ini dapat digunakan sebagai sarana untuk menumbuhkan kemampuan berpikir kritis peserta didik SMA Negeri 5 Kota Magelang.

Spesifikasi produk yang dikembangkan dalam penelitian ini berupa (1) media pembelajaran berbantuan komputer untuk pembelajaran berbasis masalah materi Pencemaran Lingkungan yang disertai dengan video. (2) Media pembelajaran berbantuan komputer untuk pembelajaran berbasis masalah berupa software yang memuat: petunjuk penggunaan, pendahuluan (berisi apersepsi dan tujuan pembelajaran), konsep dasar (berisi materi Pencemaran Lingkungan), masalah (berisi masalah dan langkah penyelesaian masalah), refleksi diri, latihan soal, daftar pustaka, glosarium, dan profil. (3) Materi yang disajikan dalam media pembelajaran berbantuan komputer untuk pembelajaran berbasis masalah ini adalah materi pelajaran Biologi Kelas X Semester 2 dengan kompetensi dasar menjelaskan keterkaitan antara kegiatan manusia dengan masalah perusakan/pencemaran lingkungan dan plestarian lingkungan. (4) Program yang digunakan berupa Adobe Flash CS3 Professional. (5) Media pembelajaran dikemas dalam bentuk file dengan format (.exe) yang dapat dioperasikan secara langsung tanpa instalasi program khusus.

Manfaat dari hasil penelitian ini dapat memberikan sumbangan bagi sekolah sebagai salah satu media pembelajaran yang dapat digunakan untuk menumbuhkan kemampuan berpikir tingkat tinggi, khususnya kemampuan berpikir kritis peserta didik. Selain itu, bagi sekolah dan pendidik dapat digunakan sebagai salah satu masukan tentang pentingnya kemampuan berpikir kritis pada peserta didik. Hasil penelitian dan pengembangan ini dapat digunakan sebagai studi pendahuluan untuk penelitian selanjutnya yang relevan.

Media pembelajaran berbantuan komputer didefinisikan sebagai multimedia yang digunakan pendidik untuk menyampaikan informasi kepada peserta didik yang dioperasikan dengan perangkat komputer. Pembelajaran berbasis masalah berupaya menempatkan peserta didik dalam menghadapi masalah yang kontekstual, kemudian mencari solusi terhadap masalah tersebut. Hasil belajar yang diperoleh peserta didik setelah proses pembelajaran difokuskan pada kemampuan berpikir kritis. Hasil belajar ditunjukkan dengan skor pretest dan post test. Critical thinking skill merupakan proses terorganisasi dalam memecahkan masalah yang melibatkan kegiatan mental yang mencakup kemampuan: fokus pada pertanyaan, memutuskan secara induksi, menganalisis argumen, membuat keputusan tentang nilai, serta memutuskan sebuah tindakan.

\section{METODE}

\section{Jenis Penelitian}

Penelitian ini merupakan jenis penelitian dan pengembangan (research and development) yang menghasilkan suatu produk. Produk yang dihasilkan berupa media pembelajaran berbantuan komputer untuk pembelajaran berbasis masalah untuk materi Pencemaran Lingkungan untuk peserta didik SMA Kelas X.

\section{Waktu dan Tempat Penelitian}

Penelitian ini dilaksanakan pada bulan Januari s.d. Juni 2013 di SMA Negeri 5 Magelang. 


\section{Subjek Penelitian}

Subjek untuk uji coba produk merupakan peserta didik SMA Negeri 5 Magelang kelas X sebanyak 29 peserta didik. Subjek ntuk uji coba lapangan meliputi peserta didik kelas X SMA Negeri 5 Magelang.

\section{Prosedur}

Prosedur penelitian ini memodifikasi model ADDIE yang terdiri atas 5 langkah, yaitu: analysis, design, develop, implementation, dan evaluate. (1) Tahap analysis terdiri atas analisis kompetensi, analisis karakteristik peserta didik, dan analisis pembelajaran. Analisis kompetensi berupa analisis terhadap kurikulum. Analisis karakteristik peserta didik dilakukan untuk mendapatkan informasi mengenai tingkat kemampuan berpikir peserta didik. Analisis pembelajaran dilakukan dengan menjabarkan tujuan pembelajarana maupun pokok bahasan yang diintegrasikan dalam media. Tahap design merupakan tahap perancangan produk dengan langkah yang terdiri dari penyusunan kerangka media, penentuan sistematika, dan pembuatan alat evaluasi. Tahap development diawali dengan pembuatan media yang menghasilkan Produk I. Produk I dinilai oleh ahli media dan ahli materi. Hasil penilaian dianalisis dan digunakan sebagai panduan untuk melakukan revisi media yang menghasilkan produk II.

Sebelum diujicobakan, produk II terlebih dahulu dinilai oleh pendidik dan teman sejawat. Hasil penilaian produk II dianalisis dan dilanjutkan dengan merevisi produk II berdasarkan masukkan yang diberikan oleh pendidik dan teman sejawat hingga menghasilkan produk III. Setelah itu media pembelajaran diujicobakan pada peserta didik secara terbatas untuk melihat keterbacaannya. Hasil uji coba terbatas dianalisis dan dilanjutkan dengan merevisi media hingga diperoleh produk IV. Setelah itu, produk IV diujicobakan ke lapangan. Berdasarkan uji coba lapangan ini diperoleh data respon siswa terhadap media, serta keterlaksanaannya. Revisi terhadap produk IV menghasilkan produk V. Tahap evaluation terdiri dari dua kegiatan yaitu penilaian dalam skala luas, serta revisi produk.

\section{Instrumen, dan Teknik Pengumpulan Data}

Data yang diperoleh terdiri atas data kelayakan media dan data pendukung. Data kelayakan media berupa data penilaian ahli materi, ahli media, pendidik, dan teman sejawat. Data kelayakan media meliputi skor penilaian aspek rekayasa perangkat lunak, aspek desain pembelajaran, dan aspek komunikasi visual. Data pendukung meliputi keterlaksanaan RPP, kemampuan berpikir kritis, dan respon peserta didik terhadap media pembelajaran berbantuan komputer.

Instrumen pengumpulan data yang digunakan dalam penelitian ini berupa angket, tes kemampuan berpikir kritis, dan lembar observasi.

\section{Teknik Analisis Data}

Teknik yang digunakan untuk menganalisis data pada penelitian ini berupa analisis deskriptif. Teknik analisis terhadap data kelayakan media dan respon peserta didik dilakukan dengan menghitung skor rata-rata kemudian mengubah skor tersebut menjadi kategori. Data yang telah terkumpul kemudian dihitung dan dikategorikan. Acuan pengubahan skor menjadi skala empat diadaptasi dari Direktorat Pembinaan SMA (2010, p.60). Konversi skor penilaian disajikan pada Tabel 1 .

Tabel 1. Konversi Skor Penilaian Ideal

\begin{tabular}{ccc}
\hline Rentang skor $(\mathbf{i})$ & Nilai & Kategori \\
\hline $\mathrm{Mi}+1,5 \mathrm{Sdi} \leq \mathrm{X} \leq \mathrm{Mi}+3 \mathrm{Sdi}$ & $\mathrm{A}$ & Sangat baik \\
$\mathrm{Mi} \leq \mathrm{X}<\mathrm{Mi}+1,5 \mathrm{Sdi}$ & $\mathrm{B}$ & Baik \\
$\mathrm{Mi}-1,5 \mathrm{Sdi} \leq \mathrm{X}<\mathrm{Mi}$ & $\mathrm{C}$ & Cukup \\
$\mathrm{Mi}-3 \mathrm{Sdi} \leq \mathrm{X}<\mathrm{Mi}-1,5 \mathrm{Sdi}$ & $\mathrm{D}$ & Kurang \\
\hline
\end{tabular}

Penelitian ini menentukan nilai kelayakan didasarkan pada nilai minimal $\mathrm{C}$ yang berkategori cukup baik. Untuk analisis data keterlaksanaan pembelajaran dilakukan dengan menghitung persentasenya.

Teknik analisis data kemampuan berpikir kritis diawali dengan uji normalitas untuk melihat normalitas distribusi data. Setelah itu dilanjutkan dengan uji beda dua rata-rata secara nonparametrik sampel yang berpasangan atau uji Wilcoxon dengan menggunakan program SPSS 16.0. Pemaknaan data dilihat melalui $\mathrm{p}$ value (signifikansi), yaitu apabila $p$ value (signifikansi) $\leq 0,05$, maka tidak signifikan, demikian sebaliknya jika $p$ value (signifikansi) > 0,05 maka signifikan (Paidi, 2012, p.62).

\section{HASIL DAN PEMBAHASAN}

Kompetensi yang dikembangkan dalam media pembelajaran berbantuan komputer ini adalah menganalisis hubungan antara komponen ekosistem, perubahan materi dan energi serta peranan manusia dalam keseimbangan ekosistem (SK: 4), dengan Kompetensi Dasar, yaitu menjelaskan keterkaitan antara kegiatan 
manusia dengan masalah perusakan/pencemaran lingkungan dan pelestarian lingkungan (KD: 4.2). Tujuan pembelajaran yang ingin dicapai pada materi ini adalah peserta didik dapat: mengidentifikasi permasalahan lingkungan, mengidentifikasi 3 faktor penyebab terjadinya pencemaran lingkungan, menunjukkan 3 dampak kerusakan lingkungan terhadap keseimbangan lingkungan, menunjukkan 1 contoh pemecahan masalah pencemaran lingkungan, dan menunjukkan kesadaran diri dalam menjaga kelestarian lingkungan.

Data yang diperoleh dari pengembangan media pembelajaran berbantuan komputer untuk pembelajaran berbasis masalah ini sebanyak 3 macam, yaitu data hasil penilaian produk, data hasil uji coba terbatas, dan data hasil uji coba lapangan.

\section{Data Penilaian Produk}

Data kelayakan media berupa data penilaian oleh ahli materi, ahli media, pendidik, dan teman sejawat. Penilaian ahli dilakukan oleh dua orang ahli materi dan seorang ahli media. Data hasil penilaian oleh ahli materi dan media dapat dilihat pada Tabel 2.

Tabel 2. Data Hasil Penilaian oleh Ahli Materi dan Ahli Media

\begin{tabular}{cc}
\hline Aspek Penilaian & Skor Rerata \\
\hline Rekayasa Perangkat Lunak & 18 \\
Desain Pembelajaran & 58,5 \\
Komunikasi Visual & 52,5 \\
\hline
\end{tabular}

Berdasarkan konversi skor penilaian skala empat untuk hasil evaluasi oleh ahli media dan ahli materi, dinyatakan bahwa media pembelajaran berbantuan komputer untuk pembelajaran berbasis masalah untuk aspek rekayasa perangkat lunak diperoleh nilai B dengan kategori baik, sedangkan untuk aspek desain pembelajaran dan aspek komunikasi visual dengan nilai A yang berkategori sangat baik.

Penilaian kedua dilakukan oleh empat pendidik mata pelajaran Biologi. Data hasil penilaian oleh pendidik disajikan pada Tabel 3 .

Tabel 3. Data Hasil Penilaian oleh Pendidik

\begin{tabular}{cc}
\hline Aspek Penilaian & Skor Rerata \\
\hline Rekayasa Perangkat Lunak & 20 \\
Desain Pembelajaran & 22,25 \\
Komunikasi Visual & 49,25 \\
\hline
\end{tabular}

Penilaian media oleh teman sejawat terdiri dari lima orang. Data hasil penilaian oleh teman sejawat disajikan pada Tabel 4.
Tabel 4.Data Hasil Evaluasi Teman Sejawat

\begin{tabular}{cc}
\hline Aspek Penilaian & Skor Rerata \\
\hline Rekayasa Perangkat Lunak & 21,2 \\
Desain Pembelajaran & 24,8 \\
Komunikasi Visual & 54,2 \\
\hline
\end{tabular}

Berdasarkan konversi skor penilaian skala empat untuk hasil evaluasi pendidik dan teman sejawat dinyatakan bahwa media pembelajaran berbantuan komputer untuk pembelajaran berbasis masalah untuk aspek rekayasa perangkat lunak mendapatkan nilai A dengan kategori sangat baik. Media pembelajaran berbantuan komputer untuk pembelajaran berbasis masalah ini untuk aspek desain pembelajaran mendapatkan hasil penilaian dari pendidik dengan nilai B yang berkategori baik, sedangkan dari teman sejawat diperoleh nilai A dengan kategori sangat baik. Media pembelajaran berbantuan komputer untuk pembelajaran berbasis masalah hasil pengembangan untuk aspek komunikasi visual mendapatkan penilaian dari pendidik dengan nilai B yang berkategori baik, sedangkan dari teman sejawat dengan nilai A yang berkategori sangat baik.

\section{Data Hasil Uji Coba Terbatas}

Uji coba terbatas dilakukan untuk melihat keterbacaan media pembelajaran berbantuan komputer untuk pembelajaran berbasis masalah oleh peserta didik, sehingga data yang diperoleh berupa data respon peserta didik terhadap produk yang dikembangkan. Data hasil respon peserta didik pada uji coba terbatas disajikan pada Tabel 5 .

Tabel 5. Data Hasil Respon Peserta Didik pada Uji Coba Terbatas

\begin{tabular}{cc}
\hline Aspek Penilaian & Skor Rerat \\
\hline Rekayasa Perangkat Lunak & 10,1 \\
Desain Pembelajaran & 13,1 \\
Komunikasi Visual & 24,7 \\
\hline
\end{tabular}

Berdasarkan konversi skor penilaian skala empat untuk data respon peserta didik dapat disimpulkan bahwa respon peserta didik terhadap media pembelajaran untuk tiga aspek, yaitu aspek rekayasa perangkat lunak, aspek desain pembelajaran, dan aspek komunikasi visual masuk dalam kategori sangat baik.

\section{Data Hasil Uji Coba Lapangan}

Data yang diperoleh dari kegiatan pembelajaran pada uji coba lapangan terdiri dari keterlaksanaan pembelajaran, respon peserta 
didik, dan ketercapaian kemampuan berpikir kritis.

\section{Keterlaksanaan Proses Pembelajaran}

Pembelajaran Biologi menggunakan media pembelajaran berbantuan komputer untuk pembelajaran berbasis masalah pada penelitian ini menggunakan sintaks pembelajaran berbasis masalah yang terdiri dari 5 tahap, yaitu orientasi peserta didik pada permasalahan, pengorganisasian peserta didik untuk meneliti, investigasi kelompok, pengembangan dan presentasi hasil karya, serta analisis dan evaluasi proses mengatasi masalah.

Pelaksanaan pembelajaran pada uji coba lapangan diamati oleh satu observer. Penilaian keterlaksanaan RPP diperoleh data bahwa keterlaksanaan pembelajaran sebesar $80 \%$, pembelajaran tahap 1-4 dapat terlaksana, sedangkan tahap 5 tidak terlaksana secara penuh. Tahap 5 berupa tahap analisis dan eva-luasi proses mengatasi masalah.

\section{Respon Peserta Didik}

Data respon peserta didik yang diperoleh pada uji coba lapangan meliputi tiga aspek seperti pada Tabel 6. Berdasarkan konversi skor penilaian skala empat data respon peserta didik, dapat ditarik kesimpulan bahwa respon peserta didik didasarkan pada tiga aspek, yaitu aspek rekayasa perangkat lunak, aspek desain pembelajaran, dan aspek komunikasi visual yang semuanya berkategori baik.

Tabel 6. Data Respon Peserta Didik pada Uji Coba Lapangan

\begin{tabular}{cc}
\hline Aspek Penilaian & Skor Rerata \\
\hline Rekayasa Perangkat Lunak & 9,5 \\
Desain Pembelajaran & 12,2 \\
Komunikasi Visual & 21,5 \\
\hline
\end{tabular}

\section{Ketercapaian Kemampuan Berpikir Kritis}

Pengukuran kemampuan berpikir kritis pada peserta didik dilakukan melalui pretest dan posttest. Pemberian pretest bertujuan untuk mengukur kemampuan berpikir kritis peserta didik sebelum pembelajaran, sedangkan posttest untuk mengukur kemampuan berpikir kritis peserta didik setelah pembelajaran. Peserta didik yang mengikuti pretest dan posttest sebanyak 30 orang. Berdasarkan data hasil pengukuran yang telah dilakukan diperoleh rerata skor pretest sebesar 4,93 dan rerata skor posttest sebesar 7,32 .
Uji normalitas dilakukan terhadap data skor pretest dan posttest. Hasil uji normalitas terhadap data pretest menunjukkan sig. 0,001 yang skor ini kurang dari 0,05 , sehingga data pretest tidak berdistribusi normal. Untuk hasil uji normalitas terhadap data posttest dengan nilai signifikansi sebesar 0,061 yang menunjukkan bahwa data posttest terdistribusi normal.

Data skor pretest tidak memenuhi syarat terdistribusi normal, sehingga analisis dengan uji t berpasangan tidak dapat dilakukan. Untuk mengetahui nilai beda dua buah rata-rata pada data yang terdistrubusi tidak normal digunakan uji beda dua buah rata-rata secara nonparametrik.

Berdasarkan hasil analisis dapat diketahui bahwa hasil pengujian menunjukkan harga $\mathrm{Z}$ 4,641 dengan sig. (2-tailed) 0,000. Nilai sig. (2tailed) jauh lebih kecil dari batas kesalahan 5\%, sehingga tidak berbeda secara signifikan. Sehubungan dengan itu dapat disimpulkan bahwa tidak ditemukan perbedaan yang signifikan antara kemampuan berpikir kritis peserta didik setelah dengan sebelum pembelajaran.

Revisi terhadap media pembelajaran dilakukan berdasarkan tanggapan dari ahli media, ahli materi, pendidik, teman sejawat, dan peserta didik. Pada penelitian ini dilakukan empat kali revisi, yaitu revisi pertama setelah mendapatkan tanggapan dari ahli materi dan ahli media. Revisi kedua dilakukan setelah mendapatkan masukan dari pendidik dan teman sejawat. Revisi ketiga dilakukan setelah peserta didik memberikan respon terhadap media pembelajaran pada uji coba terbatas. Revisi keempat dilakukan setelah peserta didik memberikan respon terhadap media pembelajaran pada uji coba lapangan.

Purwanto dan Sadjanti (Padmo, 2004, p.436) menyatakan bahwa bahan ajar yang baik memenuhi 5 kriteria, yaitu kriteria tentang isi, penyajian, ilustrasi, unsur pelengkap, dan kualitas fisik. Tiga aspek penilaian media pembelajaran yang digunakan meliputi lima kriteria tersebut. Hasil analisis terhadap data penilaian media pembelajaran oleh ahli materi dan ahli media, pendidik, dan teman sejawat serta respon peserta didik menunjukkan bahwa media pembelajaran berbantuan komputer untuk pembelajaran berbasis masalah termasuk dalam kategori media pembelajaran yang baik, sehingga layak untuk digunakan dalam pembelajaran.

Pelaksanaan uji coba lapangan bertujuan untuk mengetahui pengaruh media pembelajaran 
berbantuan komputer untuk pembelajaran berbasis masalah terhadap kemampuan berpikir kritis peserta didik. Hasil analisis data uji coba lapangan menunjukkan bahwa media pembelajaran ini dapat meningkatkan kemampuan berpikir kritis peserta didik. Berdasarkan hasil temuan tersebut diketahui bahwa penggunaan media pembelajaran berbantuan komputer untuk pembelajaran berbasis masalah dapat merangsang peserta didik untuk berpikir kritis. Hasil ini sesuai dengan penelitian yang dilakukan oleh McMahon (2009), yang menunjukkan korelasi signifikan antara kemampuan komputer peserta didik dengan level kemampuan berpikir kritis.

Hasil analisis terhadap data uji coba lapangan juga sesuai dengan hasil penelitian yang dilakukan oleh Arnyana (2005), Yuan et al.(2008), dan Ali \& Rubani (2009). Secara garis besar hasil tiga penelitian ini menunjukkan bahwa penerapan PBL dapat meningkatkan kemampuan berpikir kritis peserta didik. Salah satu karakteristik PBL menggunakan masalah sebagai starting point dalam pembelajarannya. Media pembelajaran ini menggunakan permasalahan sebagai perhatian utama.

Sebagai produk hasil pengembangan, media pembelajaran berbantuan komputer untuk pembelajaran berbasis masalah ini memiliki kelebihan dan kelemahan. Kelebihan produk di antaranya media ini memuat gambar, sehingga peserta didik lebih mudah memahami materi Pencemaran Lingkungan, menggunakan animasi teks, warna serta suara audio yang dapat menarik perhatian peserta didik dalam proses pembelajaran. Selain itu penyajian masalah lingkungan diserati dengan video dan bimbingan dalam memecahkan masalah. Media ini dirancang sebagai alat bantu pendidik dalam proses pembelajaran agar menciptakan pembelajaran yang menyenangkan dan membawa masalah lingkungan ke dalam kelas untuk dipecahkan oleh peserta didik. Selain itu, media ini dirancang untuk dapat membantu meningkatkan kemampuan berpikir kritis peserta didik.

Media pembelajaran berbantuan komputer untuk pembelajaran berbasis masalah ini juga memiliki kelemahan antara lain hanya terbatas pada satu materi, yaitu Pencemaran Lingkungan. Media juga memiliki ketergantungan yang besar pada perangkat komputer atau laptop atau perangkat yang dapat menayangkan program dari media ini.

\section{SIMPULAN DAN SARAN}

\section{Simpulan}

Berdasarkan hasil penelitian dan pembahasan yang telah dilakukan, dapat disimpulkan bahwa: (1) media pembelajaran berbantuan komputer untuk PBL layak digunakan sebagai media dalam proses pembelajaran, serta (2) media pembelajaran berbantuan komputer untuk PBL pada materi Pencemaran Lingkungan mampu meningkatkan kemampuan berpikir kritis peserta didik SMA Negeri 5 Kota Magelang secara efektif.

\section{Saran}

Saran yang disampaikan dalam tulisan ini adalah (1) kepada pendidik dapat menggunakan media pembelajaran berbantuan komputer untuk pembelajaran berbasis masalah untuk materi Pencemaran Lingkungan untuk meningkatkan kemampuan berpikir kritis peserta didik. (2) perlu pengembangan produk lebih lanjut dalam skala luas untuk mengetahui kelayakan produk yang tidak terbatas pada satu materi saja.

\section{DAFTAR PUSTAKA}

Arnyana, I.D.P. (2005). Pengaruh penerapan model pbl dipandu strategi kooperatif terhadap kecakapan berpikir kritis siswa sma pada mata pelajaran biologi. Jurnal Pendidikan dan Pengajaran IKIP Negeri Singaraja, 2005, p.646.

Ali, A.H. \& Rubani, .N.K. (November 2009). Student-centered learning: an approach in physics learning style using problembased learning (pbl) method. Makalah disajikan dalam International Conference on Teaching and Learning in Higher Education 2009 (ICTLHE09), di Kuala Lumpur.

Direktorat Pembinaan SMA. (2010). Juknis pengembangan bahan ajar SMA. Diakses tanggal 3 April 2013 dari http://suaidinmath.files.wordpress.com/ 2011/01/30-juknis-penilaianafektif_isi-revisi_0104.pdf.

Johnson, E.B. (2009). Contextual teaching and learning $\left(7^{\text {th }} e d\right)$. (Terjemahan Ibnu Setiawan). California: Corwin Press, Inc. (Buku asli diterbitkan tahun 2002).

McMahon, G. (2009). Critical thinking and ICT integration in a western australian 
64 - Jurnal Inovasi Pendidikan IPA, Volume 1 - Nomor 1, April 2015

secondary school. Educational Technology \& Society, 12 (4), pp.269-281.

Padmo, D., Julaeha, S., Puspitasari, K. A., \& Ibrahim, N. (2004). Teknologi pembelajaran. Jakarta: Pusat Teknologi Komunikasi dan Informasi Pendidikan.

Paidi. (2011). Panduan praktikum biometri. Yogyakarta: Jurdik biologi MIPA UNY. (Tidak Diterbitkan).
Sanjaya, W. (2008). Strategi pembelajaran berorientasi standar proses pendidikan. Jakarta: Kencana.

Winarno; Yasid, A., Marzuki, R., Rini, S. E. S., \& Amaliah, S. (2009). Teknik evaluasi multimedia pembelajaran. Genus Prima Media.

Yuan, H., Kunaviktikul, W., Klunklin, A., et al. (2008). Promoting critical thinking skills through problem-based learning. CMU, Journal of Soc. Sci. and Human, 2 (2), pp.85-100. 